\title{
Chronic heart failure and hypotensive effects of sacubitril/valsartan. A clinical case
}

\author{
Claudia Morabito ${ }^{a}$, Marianna Gigliotti De Fazio ${ }^{a}$, Francesca Parisia, \\ Elisabetta Demurtas ${ }^{a}$, Luana Orlando ${ }^{a}$, Michele Scaranob \\ ${ }^{a}$ Department of Clinical and Experimental Medicine, University of Messina, Messina, Italy \\ ${ }^{b}$ Cardiology Unit, Emergency Dept, Hospital "Madonna del Soccorso", San Benedetto del Tronto, Italy
}

\section{ARTICLE INFO}

Article history:

Submitted: 23. 3. 2021

Accepted: 6. 6. 2021

Available online: 25.11 .2021

\section{Klíčová slova:}

Entresto ${ }^{\mathrm{TM}}$

Hypotenze

Kvalita života

Sacubitril/valsartan

Srdeční selhání

\section{SOUHRN}

Kontext: Srdeční selhání (heart failure, HF) se sníženou ejekční frakcí (HF with reduced ejection fraction HFrEF) představuje závažný problém veřejného zdraví, protože je diagnostikováno u více než $2 \%$ obecné populace. Farmakoterapie je založena na podávání řady léčiv s prokázaným účinkem na snížení mortality a počtu hospitalizovaných osob. Přes důrazná oficiální doporučení (guidelines) kardiologických společností dávkování léčiv v rutinní klinické praxi tradičně nevede $\mathrm{k}$ dosažení hodnot krevního tlaku uváděných v klinických studiích. Zdá se, že stejně je tomu v prýípadě kombinace sacubitril/valsartan, její přínos je nicméně uspokojivý.

Kazuistika: Popisujeme př́ipad 67letého muže s HFrEF v důsledku dilatační kardiomyopatie, u něhož byla zahájena léčba kombinací sacubitril/valsartan. Pro nízký krevní tlak nebyl pacient schopen tolerovat úpravy dávek dané kombinace. Přes toto omezení byly po šesti měsících léčby dosaženy příznivé výsledky ve smyslu kvality života a funkční kapacity.

Závěr: Kombinace sacubitril/valsartan zlepšuje kvalitu života u pacientů se srdečním selháním, i když kvůli nízkému tlaku nelze podávat cílové dávky.

(c) 2021, ČKS.
Keywords: Entresto ${ }^{\mathrm{TM}}$ Heart failure Hypotension Quality of life Sacubitril/valsartan

\section{ABSTRACT}

Background: Heart failure (HF) with reduced ejection fraction (HFrEF) is a significant public health issue, affecting more than $2 \%$ of general population. Therapy includes multiple medications proven to decrease mortality and hospitalization rates. Despite strong guideline recommendations, dosing in routine clinical practice has traditionally failed to reach the same levels achieved in clinical trials. The same seems to occur with sacubitril/valsartan but the benefits are still satisfactory.

Case presentation: We report the case of a 67-year-old male patient suffering from HFrEF resulting from dilated cardiomyopathy who started therapy with sacubitril/valsartan. The patient was unable to tolerate dose adjustments of the drug due to low blood pressure. Despite this limitation, good results in terms of quality of life and functional capacity have been reached after six months of treatment.

Conclusion: Sacubitril/valsartan improves quality of life in patients with heart failure even when target dose is not reached due to low blood pressure. 


\section{Background}

$\mathrm{HF}$ is a clinical syndrome characterized by breathlessness, ankle swelling, and fatigue that may be accompanied by signs as elevated jugular venous pressure, pulmonary crackles, and peripheral oedema caused by a structural or functional cardiac abnormality, resulting in a reduced cardiac output and elevated intracardiac pressures at rest or during stress. Transthoracic echocardiography is the first-line imaging modality. ${ }^{1-3}$ With an estimated prevalence of $2 \%$ in general population and over 23 million people worldwide, heart failure (HF) is a growing emergency. Despite the use of guideline-directed medical therapies such as angiotensin-converting enzyme inhibitors, beta-adrenergic blockers, angiotensin receptor blockers, and mineralocorticoid receptor antagonists HF remains a leading cause of morbidity, mortality, and health care expenditures. Recently, a new therapeutic class called ARNI (angiotensin receptor neprilysin inhibitor) has been developed, acting on the renin-angiotensin-aldosterone system (RAAS) and the neutral endopeptidase system. Sacubitril/valsartan is the first drug belonging to this class and for sure the newest strategy in HF therapy as already recommended by the latest guidelines. ${ }^{4-8}$

\section{Case presentation}

A 67-year-old male patient was admitted to the Cardiology ward of our Center due to worsening heart failure. The diagnosis occurred in the first place two years before when the patient underwent echocardiography suggested by his Family Doctor to explore the cause of a new onset dyspnea; the exam showed dilated cardiomyopathy, confirmed by coronary angiography that found no significant lesions. Since then, the patient was taking medical therapy with bisoprolol $5 \mathrm{mg}$ o.d., enalapril $5 \mathrm{mg}$ o.d., spironolactone $50 \mathrm{mg}$ o.d. and furosemide $25 \mathrm{mg}$ as needed. ${ }^{8}$

At hospital admission, the patient presented with a NYHA Class III HFrEF despite optimal medical therapy with swelling of the feet and ankles, fatigue, palpitation (95 bpm) and dyspnea. Blood pressure was $125 / 70 \mathrm{mmHg}$, $\mathrm{SpO}_{2} 91 \%$. We performed ECG that showed sinus rhythm, as already shown in older tracings, and echocardiography that confirmed the diagnosis of left ventricle volume overload with reduced ejection fraction (EF) around $30 \%$. Blood samples were taken to assess complete blood count, renal function, electrolytes and B-type natriuretic peptide (BNP). Except BNP (856 pg/dl) everything else was fine so we decided to administer i.v. loop diuretics to reduce volume overload while monitoring blood pressure to avoid hypotension. In a couple of days the patient was discharged with the same therapy, except for furosemide that was given every day b.i.d., and with an outpatient appointment after one month to offer consultation and monitoring of developments in the treatment program. When we met again, the patient had exertional dyspnea and referred fatigue during daily activities (NYHA III). We administered the Kansas City Cardiomyopathy Questionnaire (KCCQ) to the patient and he underwent the six-minute walk test (6MWT) to assess his physical limitations due to heart failure. Then we repeated echocardiography, performing global longitudinal strain (GLS) evaluation, ${ }^{9-13}$ and checked again for renal function (K 4, 1 $\mathrm{mg} / \mathrm{dl}, \mathrm{Na} 140 \mathrm{mg} / \mathrm{dl}$, creatinine $0.8 \mathrm{mg} / \mathrm{dl}$ ), BNP (633 pg/ dl), N-terminal pro-B-type natriuretic peptide (NT-proBNP) $(971 \mathrm{pg} / \mathrm{dl})$ and blood pressure $(110 / 70 \mathrm{mmHg})$. After careful evaluation of all test results, we decided to switch from previous therapy with enalapril $5 \mathrm{mg}$ o.d. to sacubi-

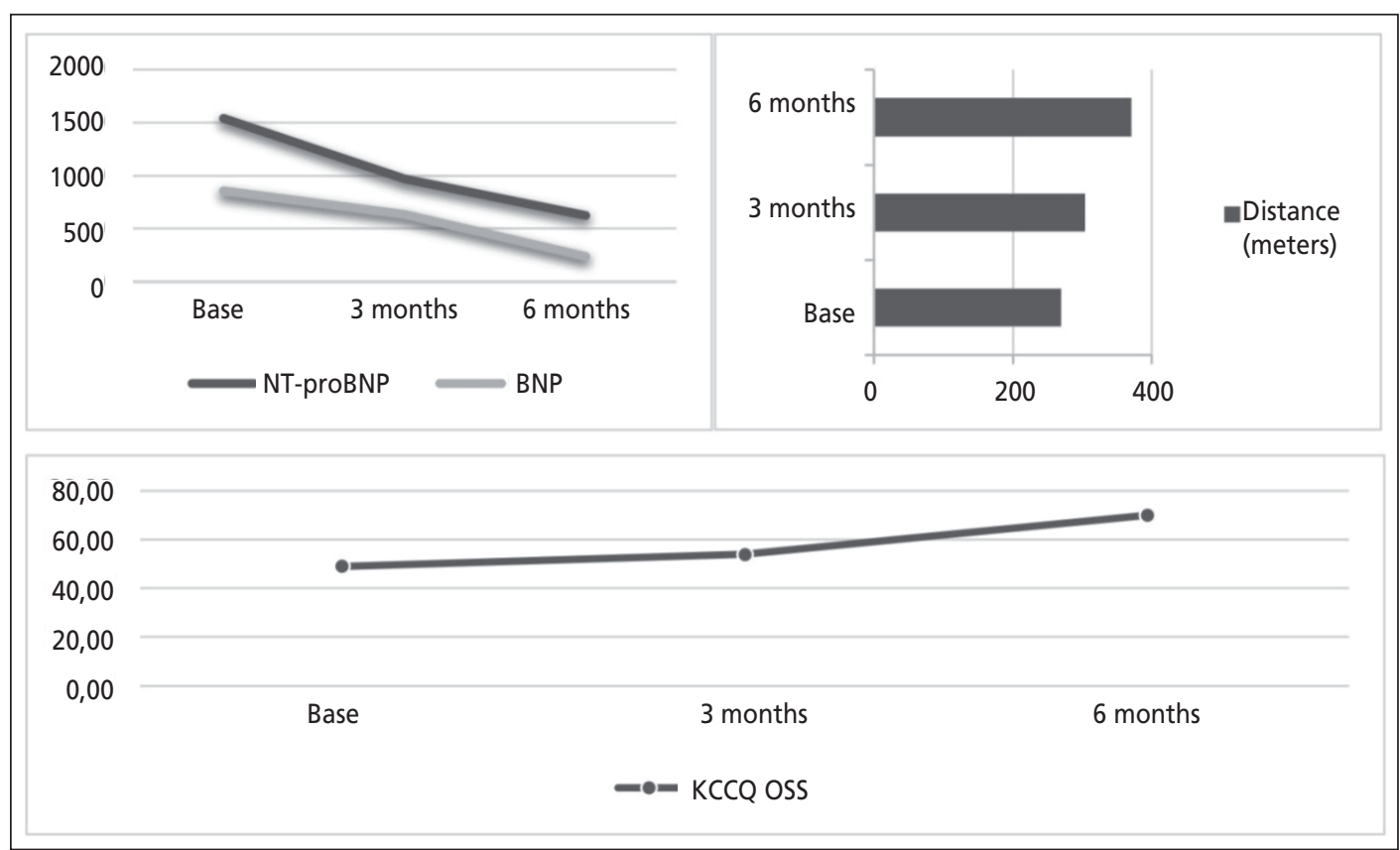

Fig. 1 - A close follow up during the first 6 months of treatment with sacubitril/valsartan demontrated a reduction of NT-proBNP and BNP levels. Functional capacity, evaluated by the 6MWT, improved from baseline to 6 months. The KCCQ showed major improvements in self-assessed quality of life. 
tril/valsartan $24 / 26 \mathrm{mg}$ b.i.d. and we planned a close foIlow up. ${ }^{14-18}$ The patient was examined every 3 months for one year. After 12 weeks of treatment exertional dyspnea completely disappeared and fatigue reduced significantly. The KCCQ showed major improvements in self-assessed quality of life while the 6MWT results were remarkable with 42 more meters walked in 6 minutes. BNP reduced slightly and NT-proBNP levels decreased by $35 \%$. Encouraged by these results we titrated sacubitril/valsartan to $49 / 51 \mathrm{mg}$ b.i.d., reducing furosemide to $25 \mathrm{mg}$ o.d.

Ten days after, patient's wife reached us on the phone to tell us her husband was feeling worse, tired, and dizzy, and that his blood pressure was around $90 / 60 \mathrm{mmHg}$. We checked him up and reverted sacubitril/valsartan to the lower dosage to prevent hypotension. Six months after starting therapy with ARNI, improvement of early symptoms was stable despite unoptimized therapy. ${ }^{14,15} \mathrm{KCCQ}$ Overall Summary Score improved by 13 points while functional capacity increased by $30 \%$. BNP levels were lower (237 pg/dl) as NT-proBNP levels (624 pg/dl) (Fig. 1).

\section{Discussion}

The goals of treatment in patients with HF are to improve their clinical status, functional capacity, and quality of life, prevent hospital admission, and reduce mortality. Neuro-hormonal antagonists (ACEls, MRAs and beta-blockers) have been shown to improve survival in patients with HFrEF and are recommended for the treatment of every patient with $\mathrm{HFrEF}$, unless contraindicated or not tolerated. ${ }^{1}$ Sacubitril/valsartan is therefore recommended to replace ACEIs in ambulatory HFrEF patients who remain symptomatic despite optimal therapy. ${ }^{1,6,14,15}$ There is evidence that in clinical practice the majority of patients receive suboptimal doses of ACEI. The same seems to be true with ARNI; ${ }^{6-8,14,15}$ however, in our case, sacubitril/valsartan improvements over quality of life and functional capacity remained equally impressive. Though our patient never reached optimal titration (sacubitril/valsartan 97/103 mg b.i.d.), exertional dyspnea and fatigue reduced significantly in three months of treatment and the improved health status was stable over the following weeks. Our patient never required another admission at our hospital throughout the whole year of follow up. He only experienced one minor and transient hypotensive episode, quickly fixed by down titrating sacubitril/valsartan to the lower dosage. It appears that patients with HFrEF who already take optimal medical therapy but still suffer from typical symptoms may benefit from an upgraded therapy with sacubitril/valsartan even when low blood pressure levels could stop the physician from prescribing the drug. We observed that quality of life and functional capacity are quickly enhanced by the drug at its lowest dosage despite the impossibility to up titrate it.

\section{Conclusions}

The present case shows how quality of life improvements in patients with $\mathrm{HFrEF}$ can be achieved with sacubitril/valsartan even when target dose is not reached due to low blood pressure. Sacubitril/valsartan appears safe, well tolerated, with few risks for adverse effects.

\section{Acknowledgements}

None declared.

\section{Conflict of interest}

The authors declare no conflict of interest, financial or otherwise.

\section{Ethical statement}

Not applicable.

\section{Informed consent}

A written informed consent was obtained from the patient for this study.

\section{References}

1. Ponikowski P, Voors AA, Anker SD, et al. 2016 ESC Guidelines for the diagnosis and treatment of acute and chronic heart failure: The Task Force for the diagnosis and treatment of acute and chronic heart failure of the European Society of Cardiology (ESC). Developed with the special contribution of the Heart Failure Association (HFA) of the ESC. Eur Heart J 2016;37:2129-2200.

2. Camplain R, Kucharska-Newton A, Keyserling TC, et al. Incidence of heart failure observed in emergency departments, ambulatory clinics, and hospitals. Am J Cardiol 2018;11:13281335.

3. Jones NR, Roalfe AK, Adoki I, et al. Survival of patients with chronic heart failure in the community: a systematic review and meta-analysis. Eur J Heart Fail 2019;21:1306-1325.

4. Scrutinio D, Passantino A, Guida P, et al. Prognostic impact of comorbidities in hospitalized patients with acute exacerbation of chronic heart failure. Eur J Intern Med 2016;34:63-67.

5. Imbalzano E, Dattilo G, Scarpelli M, et al. Left coronary artery fistula to right ventricle complicated heart failure in a patient on hemodialysis. Intern Emerg Med 2013;8:765-766.

6. McMurray JJ, Packer M, Desai AS, et al. PARADIGM-HF Committees and Investigators. Dual angiotensin receptor and neprilysin inhibition as an alternative to angiotensin-converting enzyme inhibition in patients with chronic systolic heart failure: rationale for and design of the Prospective comparison of ARNI with ACEI to Determine Impact on Global Mortality and morbidity in Heart Failure trial (PARADIGM-HF). Eur J Heart Fail 2013;15:1062-1073.

7. Imbalzano E, Scarpelli M, Mandraffino G, et al. Combination therapy with aliskiren versus ramipril or losartan added to conventional therapy in patients with type 2 diabetes mellitus, uncontrolled hypertension and microalbuminuria. J Renin Angiotensin Aldosterone Syst 2015;16:956-964.

8. Yancy CW, Jessup M, Bozkurt B, et al. 2017 ACC/AHA/HFSA focused update of the 2013 ACCF/AHA guideline for the management of heart failure: a report of the American College of Cardiology/American Heart Association Task Force on Clinical Practice Guidelines and the Heart Failure Society of America. Circulation 2017;136:e137-e161.

9. Pettersen KI, Reikvam A, Rollag A, et al. Reliability and validity of the Kansas City cardiomyopathy questionnaire in patients with previous myocardial infarction. Eur J Heart Fail 2005; 7:235-242.

10. McCabe N, Butler J, Dunbar SB, et al. Six-minute walk distance predicts 30-day readmission after acute heart failure hospitalization. Heart Lung 2017;46:287-292.

11. Dattilo G, Imbalzano $E$, Lamari A, et al. Ischemic heart disease and early diagnosis. Study on the predictive value of 2D strain. Int J Cardiol 2016;215:150-156.

12. Imbalzano E, Saitta A, Lamari A, et al. Echo-Doppler evaluation of recent onset chronic venous insufficiency in elderly patients: does the heart have a role? Recenti Prog Med 2013;104:569-573. 
13. de Gregorio C, Dattilo G, Casale M, et al. Left Atrial Morphology, Size and Function in Patients With Transthyretin Cardiac Amyloidosis and Primary Hypertrophic Cardiomyopathy - Comparative Strain Imaging Study. Circ J 2016;80:1830-1837.

14. de Gregorio C, Laterra G, Vaccaro V, et al. Time-based clinical and functional achievements in real-life HF patients on ARNI treatment. Eur J Intern Med 2020;76:115-117.

15. Casale M, Correale M, Laterra G, et al. Effects of Sacubitril/ Valsartan in Patients with High Arrhythmic Risk and an ICD: A Longitudinal Study. Clin Drug Investig 2021;41:169-176.
16. Imbalzano E, Vatrano M, Mandraffino G, et al. Arterial stiffness as a predictor of recovery of left ventricular systolic function after acute myocardial infarction treated with primary percutaneous coronary intervention. Int J Cardiovasc Imaging 2015;31:1545-1551.

17. Casale M, Mezzetti M, De Fazio MG, et al. Usefulness of sacubitril/valsartan in reduction of atrial fibrillation burden in a patient with ICD delivering inappropriate therapies. A new possibility? Cor Vasa 2020;62:336-339.

18. Morabito C, De Fazio MG, Scarano M, et al. Sacubitril/ valsartan and implantable cardioverter-defibrillators: evolving therapeutic strategies. A case report. Cor Vasa 2020;62:479-482. 